Provided for non-commercial research and education use. Not for reproduction, distribution or commercial use.

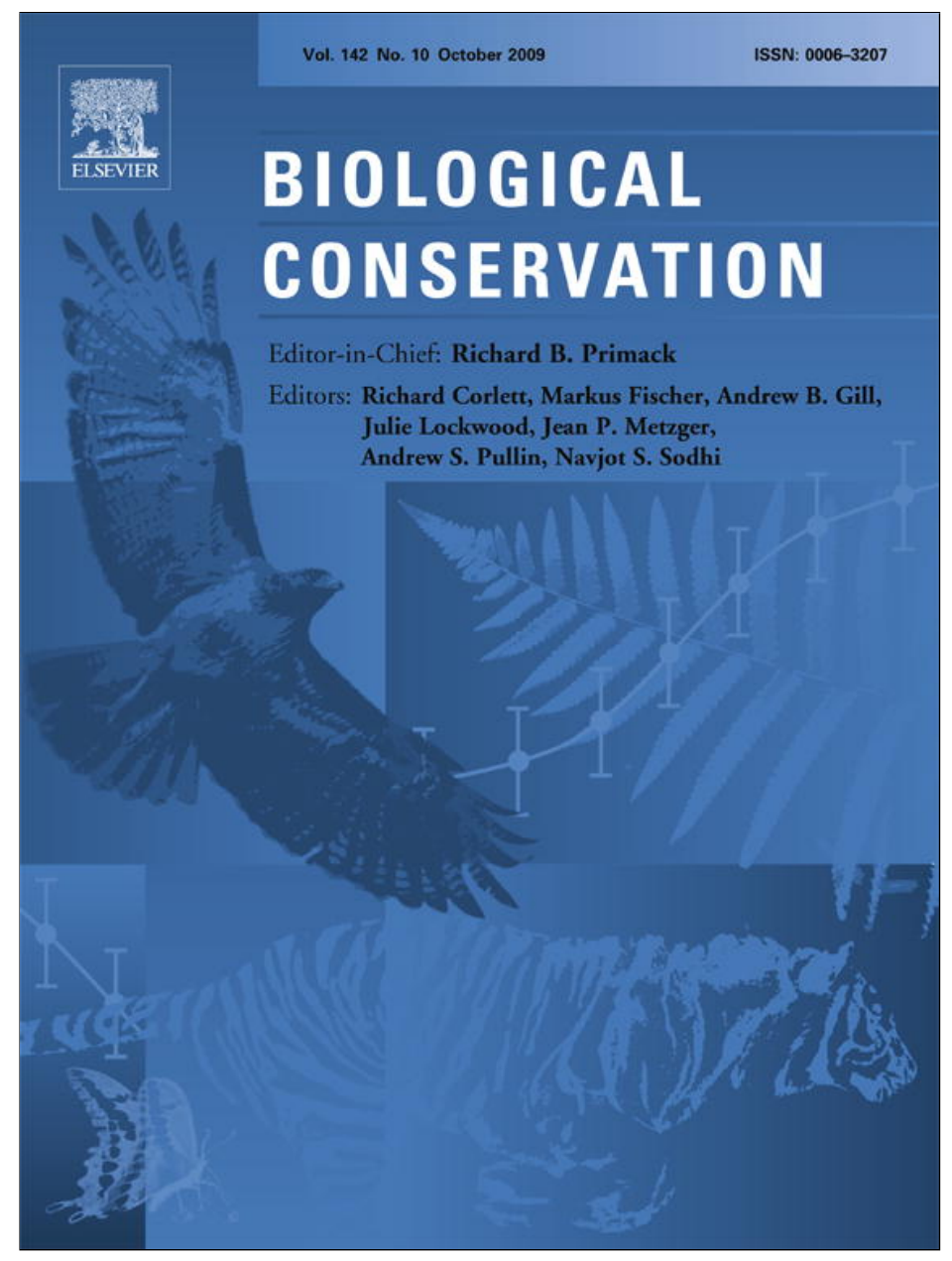

This article appeared in a journal published by Elsevier. The attached copy is furnished to the author for internal non-commercial research and education use, including for instruction at the authors institution and sharing with colleagues.

Other uses, including reproduction and distribution, or selling or licensing copies, or posting to personal, institutional or third party websites are prohibited.

In most cases authors are permitted to post their version of the article (e.g. in Word or Tex form) to their personal website or institutional repository. Authors requiring further information regarding Elsevier's archiving and manuscript policies are encouraged to visit:

http://www.elsevier.com/copyright 


\title{
Evaluating the demographic history of the Seychelles kestrel (Falco araea): Genetic evidence for recovery from a population bottleneck following minimal conservation management
}

\author{
Jim J. Groombridge ${ }^{\mathrm{a}, \mathrm{b}, *}$, Deborah A. Dawson ${ }^{\mathrm{b}}$, Terry Burke ${ }^{\mathrm{b}}$, Robert Prys-Jones ${ }^{\mathrm{c}}$, M. de L. Brooke ${ }^{\mathrm{d}}$, \\ Nirmal Shah ${ }^{\mathrm{e}}$ \\ ${ }^{a}$ Durrell Institute of Conservation and Ecology, University of Kent, Kent CT2 7NR, UK \\ ${ }^{\mathrm{b}}$ NERC Molecular Genetics Facility, Department of Animal and Plant Sciences, University of Sheffield, Western Bank, Sheffield, South Yorkshire S10 2TN, UK \\ ${ }^{\mathrm{c}}$ Bird Group, Department of Zoology, Natural History Museum, Akeman Street, Tring, Hertfordshire HP23 6AP, UK \\ ${ }^{\mathrm{d}}$ Department of Zoology, University of Cambridge, Downing Street, Cambridge CB2 3EJ, UK \\ ${ }^{\mathrm{e}}$ Nature Seychelles, P.O. Box 1310, The Centre for Environment E' Education, Roche Caiman, Mahe, Seychelles
}

\section{A R T I C L E I N F O}

\section{Article history:}

Received 27 August 2008

Received in revised form 23 April 2009

Accepted 28 April 2009

Available online 23 May 2009

\section{Keywords:}

Bottleneck

Endemic island species

Genetic diversity

Museum DNA

\begin{abstract}
A B S T R A C T
An important requirement for biologists conserving vulnerable species of wildlife and managing genetic problems associated with small population size is to evaluate existing evidence regarding what is known of a species' recent population history. For endemic island species in particular, current genetic impoverishment could be due to either a recent population crash or a consequence of an evolutionary history of sustained isolation and small effective population size. Interpreting any given case can often be further complicated by incomplete or contradictory evidence from historical field surveys that might suggest a very different demographic history. Here, we use the case of the Seychelles kestrel (Falco araea), an island endemic previously listed as critically-endangered but now relatively common, to illustrate how genetic data from microsatellite genotypes of 100-150-year-old museum specimens reveals a recent and severe population crash since the 1940 s to approximately eight individuals, before the population recovered. We re-interpret the historical population trajectory of the Seychelles kestrel in the light of the minimal intervention required for this species to recover. We examine different ecological explanations for the decline and apparently unassisted recovery of the Seychelles kestrel, review the evidence for similarly unaided recoveries elsewhere and discuss the implications of unaided population recoveries for future species conservation programmes. Demographic profiles from historical genetic signatures can provide highly informative evidence when evaluating past and future recovery efforts for endangered species.
\end{abstract}

(c) 2009 Elsevier Ltd. All rights reserved.

\section{Introduction}

The processes by which genetic and ecological factors contribute towards the extinction of wild populations, and how these factors affect endangered species endemic to islands, remain an important focus in conservation biology. Genetic factors such as loss of genetic diversity and inbreeding are believed to play a role in the increased susceptibility to extinction of island endemics (Frankham, 1998; Frankham et al., 2002; Spielman et al., 2004). However, an important additional concern for conservation biologists working to con-

* Corresponding author. Address: Durrell Institute of Conservation and Ecology, University of Kent, Kent CT2 7NR, UK. Tel.: +44 (0)1227 824097; fax: +44 (0)1227 827289.

E-mail addresses: J.Groombridge@kent.ac.uk (J.J. Groombridge), D.A.Dawson@ sheffield.ac.uk (D.A. Dawson), T.A.Burke@sheffield.ac.uk (T. Burke), R.Prys-Jones@ nhm.ac.uk (R. Prys-Jones), M.Brooke@zoo.cam.ac.uk (M. de L. Brooke), Nirmalshah@ natureseychelles.org (N. Shah). serve small island populations is a clear understanding of the recent population history of a species. In particular, has a species maintained a stable population size from historical times to the present day or has it endured a recent population crash and, if so, what impact has this had on contemporary levels of genetic diversity? Beyond providing verification of descriptions of a species' historical abundance, answers to these questions are important for managing the future recovery of an endangered species (Matocq and Villablanca, 2001). For example, prior knowledge that a species has experienced a recent dramatic reduction in effective population size can allow managers to anticipate the problems associated with inbreeding depression that are frequently seen in restored populations of endangered species, such as lowered reproductive fitness, reduced survival and increased susceptibility to disease (Swinnerton et al., 2004; Madsen et al., 1999; Keller et al., 2002).

Fortunately, the last decade has seen the development of genetic methods to measure ancestral levels of genetic diversity that 
allow comparison with contemporary levels. Early pioneering work by Bouzat et al. (1998) and Nielsen et al. (1999) applied molecular genetic techniques to historical wild populations that were relatively abundant in the past. However, more commonly, conservation biologists managing endangered species endemic to islands have available to them information on the level of genetic diversity only in the contemporary population, allowing more than one interpretation. First, endemic island species are widely believed to have proportionately lower levels of genetic diversity than species with a continental distribution and this is considered to lead to increased levels of inbreeding and associated risks of extinction in endemic island populations (Frankham, 1997, 2005). Second, contemporary measures of genetic diversity have been shown to be lower in threatened species than in their non-threatened counterparts and this pattern has recently been shown to hold true within birds, suggesting that recent endangerment has played a role (Spielman et al., 2004; Evans and Sheldon, 2008). However, an alternative interpretation is that island species may generally be more robust to the genetic effects of recent population bottlenecks because they have evolved as isolated populations and, as a consequence, carry lighter genetic loads that are less likely to impact negatively on their ability to persist (Frankham et al., 2001; Bataillon and Kirkpatrick, 2000).

This debate surrounding endemic island species has drawn recent attention (Jamieson et al., 2006; Jamieson, 2007) and has generated renewed interest in genetic diversity in endemic island species (Groombridge, 2007). As a consequence of these different interpretations, often fuelled by a few well-documented cases where wild populations have recovered from extremely severe bottlenecks apparently unaffected by problems associated with inbreeding (Ardern and Lambert, 1997; Groombridge et al., 2000), island species can still present a dilemma for conservation management; when low levels of genetic diversity are revealed in a particular island endemic, is this a consequence of a recent event or an evolutionary history of sustained isolation? Furthermore, interpreting a given case of genetic impoverishment can often be complicated by incomplete or contradictory evidence from historical field surveys that fail to clarify the past population trajectory. Here, we use genetic markers to examine the population history of the Seychelles kestrel (Falco araea), an island species endemic to the Seychelles archipelago in the Indian Ocean. This island endemic was described in 1966 as Critically-Endangered (Vincent, 1966) but is now relatively common (IUCN, 2007), suggesting a recent and relatively unassisted population recovery.

Historical accounts described the Seychelles kestrel as 'tolerably common' in the 1860s (Newton, 1867) and 'frequently seen on nearly all the islands' in the 1930s (Vesey-Fitzgerald, 1940), whilst two contradictory reports describe the species as 'well-distributed' and 'rare' in the 1950s (Crook, 1960; Loustau-Lalanne, 1962). By 1966, the species was considered to be Critically Endangered and close to extinction (Vincent, 1966), with probably 'less than 30 birds' confined to the main island of Mahé (Gaymer et al., 1969). However, surveys in 1973 located 49 pairs and estimated a total population on Seychelles of 150-300 birds (Feare et al., 1974; Temple, 1977), and an estimated carrying capacity of approximately 370 pairs by 1981 (Watson, 1981). An evaluation of the status of the Seychelles kestrel in 1985 described the species as being far more numerous and widespread that previously thought, possibly due to under-recording in the past (Collar and Stuart, 1985). Since then, surveys in 2001-2002 suggested that the population had remained stable over the previous 25 years (Kay et al., 2002). Together, these field records raise the intriguing possibility that the Seychelles kestrel has recovered from a severe population bottleneck relatively unaided by conservation efforts, in comparison to the recovery of the Mauritius kestrel (Falco punctatus), a closely-related oceanic island endemic that was successfully rescued from the brink of extinction by 25 years of intensive conservation management (Jones et al., 1995; Groombridge et al., 2001). More broadly, instances in which small populations appear to have recovered from a population bottleneck without the aid of intensive (and often long-term and expensive) intervention warrant particular attention, because theoretical expectations predict bottlenecked populations to have reduced genetic diversity and lowered evolutionary potential and to be at risk of problems associated with inbreeding (England et al., 2003; Frankham, 1998). Therefore instances where natural populations appear to buck this trend by showing a rapid and unassisted recovery require confirmation.

Importantly, single species studies of island endemics rarely have the benefit of a natural 'control' population or one with a precisely known bottleneck history (Bouzat, 2000), particularly those species without additional populations that may have been established through conservation management, for example by sequential translocations (Taylor and Jamieson, 2008). Here, however, a 'benchmark' against which to compare the genetic and demographic history of the Seychelles kestrel is provided by the Mauritius kestrel, whose contemporary population is well-documented to have declined to just a single breeding pair in 1974 (Groombridge et al., 2001). The Mauritius kestrel population declined during the 1800 s due to habitat loss and degradation and was then reduced to a few individuals as a consequence of poisoning by DDT organochlorine pesticides (Safford and Jones, 1997). In the 1980 s and 1990s an intensive captive-breeding and reintroduction programme successfully restored the population to approximately 800-1000 birds (Jones et al., 1995). Previous genetic work using microsatellite markers detected a dramatic loss of genetic diversity and a marked reduction in effective population size $\left(N_{\mathrm{e}}\right)$ in the Mauritius kestrel (Groombridge et al., 2000; Nichols et al., 2001). This work described a pattern of relative $N_{\mathrm{e}}$ across several other continental and island kestrel species; among these, the estimate for the contemporary Seychelles kestrel was very similar to that for the Mauritius kestrel, prompting the question of whether the Seychelles kestrel has experienced a similarly severe population crash.

In this paper, we illustrate how historical genetic data from microsatellite genotypes of 100-150-year-old museum specimens of the Seychelles kestrel reveal a temporal change in effective population size in comparison to contemporary populations. We interpret the population trajectory of the Seychelles kestrel in the light of this new genetic perspective and we review different ecological explanations of the decline and recovery of this species. Finally, we review other potentially similar examples of unassisted population recoveries and discuss the need to evaluate population genetic histories when conserving endemic island species.

\section{Methods}

\subsection{Sample collection}

Blood and feather samples from Seychelles kestrels were obtained from the main island of Mahé (Lat: -4.68 , Long: 55.47) and Silhouette (Lat: -4.48 , Long: 55.23) between January 1998 and May 2004 (see Fig. 1). Wild kestrels were located by field observation and, using play-back recordings of territorial male kestrel calls, caught using a traditional bal-chatri (Berger and Mueller, 1959). A blood sample (of 20-50 microlitre volume) was obtained from the brachial wing vein of captured individuals using a $0.3-\mathrm{ml}$ U-100 micro-fine insulin syringe (Vet UK) and whole blood was mixed with $1 \mathrm{ml}$ of absolute ethanol in a screw-topped rubber sealed microfuge tube and stored at $-20^{\circ} \mathrm{C}$. All caught individuals were banded using a uniquely numbered metal band and two col- 


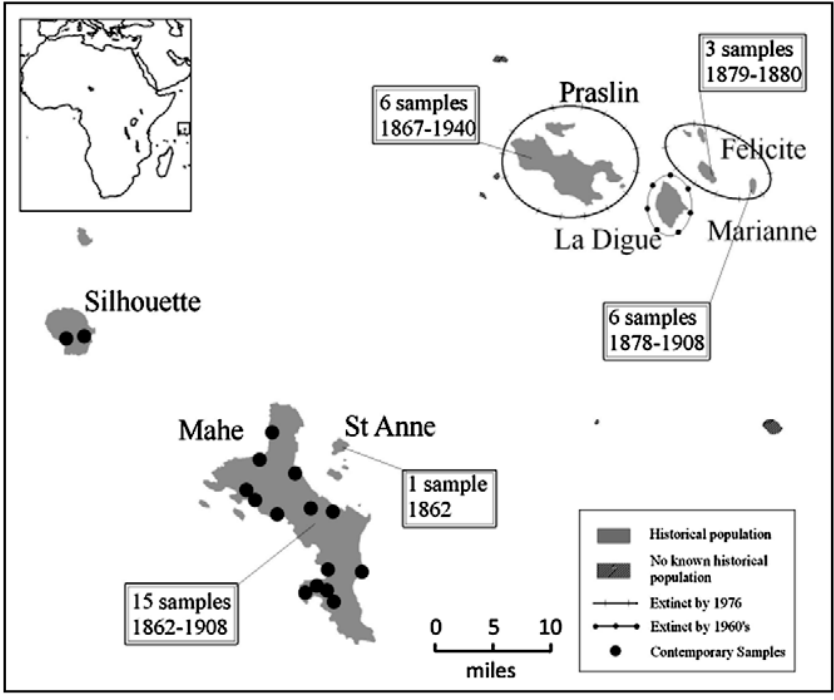

Fig. 1. Historical and contemporary range of the Seychelles kestrel, showing sampling locations for the contemporary population (circles). Boxes give the number of historical museum samples collected from each island and the range of dates for which location information was available from individual specimen labels.

oured bands to allow each bird to be individually identified in the field and to ensure no individual was sampled twice.

Samples of foot-pad tissue were obtained from all of the historical specimens of Seychelles kestrels $(n=43)$ that were available from museums worldwide. These specimens were collected in the Seychelles between ca 1840 and 1940. Previous genetic work using historical samples of the closely-related Mauritius kestrel identified foot-pad tissue samples to be the most reliable tissue type for DNA yield and for polymerase chain reaction (PCR) amplification (Groombridge et al., 2000; Nichols et al., 2001). Samples from historical specimens of Seychelles kestrels were obtained from the collections of the Natural History Museum (NHM, London, UK), the University Museum of Zoology (Cambridge, UK), the American Museum of Natural History (AMNH, New York, US), the Muséum National d'Histoire Naturelle (Paris, France) and the World Museum Liverpool. A foot-pad sample was excised from each skin using a fresh scalpel blade. Samples were stored dry at $-20^{\circ} \mathrm{C}$.

\subsection{Microsatellite genotyping}

Genomic DNA was extracted from whole blood samples of Seychelles kestrel individuals using the DNeasy Blood and Tissue Kit (Qiagen, UK). Individuals were genotyped at eleven microsatellite loci. Nine of the microsatellite loci used contained dinucleotide repeat regions and were originally isolated from the peregrine falcon (Falco peregrinus) by Nesje et al. (2000) (loci NVH-fp5, NVH-fp-46-1, NVH-fp-107, NVH-fp-89, NVH-fp-86-2, NVH-fp-31, NVH-fp-82-2, NVH-fp-13, NVH-fp-79-1; GenBank sequence accession numbers AF118420-AF118434). Two further microsatellite loci were used, respectively a hexanucleotide and tetranucleotide, both originally isolated in the European kestrel (Falco tinnunculus) (loci Fpe1, Fpe2; Jon Wetton unpublished data; see Dawnay et al., 2009; GenBank sequence accession numbers EU518686 \& EU518687).

PCR amplification of contemporary DNA was carried out in 10$\mu \mathrm{l}$ volume reactions following $5^{\prime}$ end-labelling with a fluorescent dye (TET, 6-FAM or HEX) (Integrated DNA Technologies, Inc.). Each PCR reaction contained the following: approximately $50 \mathrm{ng}$ of genomic DNA, 0.5 pmol of each primer, $1.5 \mathrm{mM} \mathrm{MgCl}, 3.0 \mathrm{mM}$ $\mathrm{NH}_{4}$ buffer (Bioline, UK) and 0.75 units Taq DNA polymerase (Bioline, UK). PCR amplification was performed in a Tetrad thermal cycler (MJ Research). Cycling parameters were as follows: $94{ }^{\circ} \mathrm{C}$ for
3 min, then 30 cycles of $94^{\circ} \mathrm{C}$ for $45 \mathrm{~s}, 58.5^{\circ} \mathrm{C}$ for $45 \mathrm{~s}$, and $72{ }^{\circ} \mathrm{C}$ for $45 \mathrm{~s}$, with a final extension step of $72^{\circ} \mathrm{C}$ for $10 \mathrm{~min}$. Each locus was amplified separately. The amplified products of some loci were pooled post-PCR but only those that had been fluorescently labelled with different dyes. PCR products were visualized using an ABI 3130 DNA Analyzer (Applied Biosystems, Warrington, UK.). TAMRA size standards and filter prism set $C$ was used and allele sizes were assigned using GENEMAPPER software (Applied Biosystems Inc.).

Genomic DNA was extracted from museum foot-pad samples of Seychelles kestrel individuals using the QiAmp DNA Micro Kit (Qiagen). The extraction protocol used was that supplied with the kit for DNA isolation from tissues, but with three modifications: (1) an additional digestion step was included in which after the finely chopped sample had been digested with Proteinase $\mathrm{K}$ during an overnight incubation at $55^{\circ} \mathrm{C},(2)$ a further $20 \mu \mathrm{l}$ of Proteinase $\mathrm{K}$ was added and the sample re-incubated at $55^{\circ} \mathrm{C}$ for a further $4 \mathrm{~h}$ to enhance full digestion of the sample, and (3) prior to extraction of the DNA: after each step of vortexing, samples were kept on ice instead of at room temperature as recommended in the protocol. All museum DNA extractions and PCR amplifications were carried out in a separate laboratory to that used for the modern DNA work For PCR amplification of museum DNA for four loci (NVH-fp-5, $\mathrm{NVH}-\mathrm{fp}-82-2, \mathrm{NVH}-\mathrm{fp}-107$ and NVH-fp-13), the cycling parameters were adjusted such that the annealing temperature was reduced from $58.5^{\circ} \mathrm{C}$ to $55^{\circ} \mathrm{C}$. All PCR amplifications for museum DNA samples were repeated three times. Negative DNA controls were carried out for all museum DNA samples. DNA extractions and amplification replicates were genotyped at all eleven loci in order to check for contamination from other individuals.

\subsection{Statistical analysis}

All loci were tested for deviation from Hardy-Weinberg equilibrium and linkage disequilibrium using GENEPOP 3.1 (Raymond and Rousset, 1995). When loci differed significantly from Hardy-Weinberg equilibrium, we applied the programme MICRO-CHECKER to identify the most likely reason for the departure (Van Oosterhout et al., 2004, 2006). Observations of heterozygote deficiency can result from the presence of null alleles, heterozygotes being misscored due to stutter bands or an artefact of non-amplification of the larger allele in heterozygotes (Wattier et al., 1998). Population genetic explanations can account for genuine heterozygote deficits, such as inbreeding or population structure. We calculated the mean number of alleles per locus and mean expected heterozygosity using CERVUS v3.0 (Kalinowski et al., 2007). Nei's gene diversity, allelic richness, pairwise $F_{\mathrm{ST}}$ values and pairwise tests for differentiation were carried out using FSTAT 2.9 (Goudet, 2001). The $F$-statistics $F_{\mathrm{IS}}, F_{\mathrm{ST}}$ and $R_{\mathrm{ST}}$ were calculated using FSTAT over all loci, to partition heterozygote deficiency into its within and among population components, in order to assess genetic structure (Weir and Cockerham, 1984). $F_{\text {IS }}$ measures the heterozygote deficit within populations and $F_{\mathrm{ST}}$ that among populations (i.e the proportion of genetic variance that can be explained by differences among populations), whilst $R_{\mathrm{ST}}$ provides an additional measure of gene differentiation that is not dependent on the number of populations sampled (Slatkin, 1995). Given that many of the historical museum specimens have location information detailing the precise island within the Seychelles archipelago from which they were collected, we also examined the genetic data from the historical population for population substructure using the programme TESS (version 1.1; Chen et al., 2007), which integrates geographical information on sampled individuals. The spatial locations of all five islands (Fig. 1) were obtained using Google Earth (2007) and random spatial coordinates were generated within each island for each of the 31 historical specimens; the resulting neighbourhood was 
modified to reflect the relative isolation of each island. TESS was run specifying a Markov Chain Monte Carlo model, an estimated number of clusters ranging from 1-7, with a burn-in period of 100,000 iterations and each model was run for 200,000 sweeps. A total of 200 runs was carried out for each model (the $20 \%$ highest likelihood runs were compared across the range of $K$ values). Finally, we applied a Bayesian method to the full microsatellite genotype data set spanning $\sim 164$ years from ca 1840 to 2004 , to detect temporal change in effective population size $\left(N_{\mathrm{e}}\right)$. This method, developed by Beaumont (2003), samples independent genealogical histories using importance sampling to estimate recent changes in $N_{\mathrm{e}}$ from temporally spaced gene frequency data and assumes that the sampling period is sufficiently short that the effects of mutations can be safely ignored. Whilst alternative Bayesian methods have been applied by Nichols et al. (2001) to estimate relative $N_{\mathrm{e}}$ for the Mauritius kestrel alongside other kestrel species, the method by Beaumont (2003) makes explicit use of historical collection dates for all of the individual museum skins, to combine historical and contemporary genetic data in a single Bayesian analysis to estimate ancestral and current $N_{\mathrm{e}}\left(N_{\mathrm{A}}\right.$ and $N_{0}$, respectively, in Beaumont, 2003). Furthermore, Beaumont's (2003) method uses the likelihood based on allele frequencies, it takes into account unequal sample sizes across loci and sampling period. In implementing Beaumont's tmvp programme for the Seychelles kestrel data, we specified a mean generation time of four years and rectangular priors of $0-1000$ for ancestral $N_{\mathrm{e}}$ and contemporary $N_{\mathrm{e}}$. To explore the model's performance, we performed analyses stipulating different values of alpha, the smoothing parameter, ranging from $\alpha=0.3-0.7$ ( $\alpha=0.3$ in the final analysis). Beaumont (2003) previously applied this Bayesian method to existing microsatellite data for the historical and contemporary populations of the Mauritius kestrel (Groombridge et al., 2000; Nichols et al., 2001). Given the well-documented single-pair bottleneck that occurred in the Mauritius kestrel population in 1974 (Jones et al., 1995; Groombridge et al., 2001), we repeat here that temporal analysis for the Mauritius kestrel as a 'benchmark' for comparison with our temporal analysis for the Seychelles kestrel.

\section{Results}

Sixteen Seychelles kestrels were caught and blood-sampled between 1998 and 2004 (four of these individuals were those used for comparative purposes in an earlier population genetic study of the Mauritius kestrel (Groombridge et al., 2000; Nichols et al., 2001). Fig. 1 shows the location of each sampled bird and the current range of the Seychelles kestrel (Kay et al., 2002, 2004). A total of 43 historical museum specimens of Seychelles kestrel was sampled for DNA (see Appendix 1 for location and date of collection of each specimen). Each of the 43 museum DNA samples yielded microsatellite genotypes for between 2 and 11 loci (giving an overall success rate of $75 \%$ for successful microsatellite amplification across all samples and loci). Eighty percent of all museum DNA genotypes were repeated at least twice to check for allelic dropout.

Only two of the 11 microsatellite loci (Fpe1 and Fpe2) were polymorphic in the contemporary Seychelles kestrel population, whereas five loci (Fpe1, Fpe2, NVH-fp5, NVH-fp46-1 and NVHfp107) were polymorphic in the historical museum samples and together contained a total of eight unique alleles not detected in the contemporary samples. None of the polymorphic loci within the contemporary population exhibited significant departure from Hardy Weinberg equilibrium. A heterozygote deficit was detected at two of the loci within the historical population. If the historical population were genetically structured, this might lead to a deficiency of heterozygotes when data from museum specimens ob-

\section{Table 1}

Comparison of measures of microsatellite genetic diversity for historical (1862-1936) and contemporary (1998-2004) populations of the Seychelles kestrel.

\begin{tabular}{lll}
\hline & Historical population & Contemporary population \\
\hline Mean alleles per locus & 2.180 & 1.450 \\
Mean allelic richness & 1.860 & 1.390 \\
Mean expected heterozygosity & 0.210 & 0.104 \\
Nei's gene diversity & 2.352 & 1.160 \\
\hline
\end{tabular}

tained on different islands or from different time periods were pooled (Wahlund effect). In support of this idea, field studies of Seychelles and other Indian Ocean kestrels show strong site fidelity and poor dispersal ability, two characteristics that tend to generate structured populations (Watson, 1992; Burgess et al., 2008). The mean number of alleles per locus, allelic richness, mean expected heterozygosity and Nei's gene diversity were all higher in the historical population compared to the contemporary population (Table 1). Despite the observed reduction in allelic richness and heterozygosity, the historical and contemporary populations were not significantly differentiated (pairwise $G$ test, $P=0.383$ ). $F_{\text {IS }}$ was higher $(0.675)$ in the historical population than the contemporary population $(0.300)$.

Locality information was available for 31 of the 43 historical museum specimens. They had been collected from five different Seychelles islands (Mahé [16], Praslin [6], Felicité [2], Ile Marianne [6] and St. Anne [1]; see Fig. 1), allowing measurement of genetic differentiation between islands (due to the close proximity of St. Anne and Mahé, samples from these locations were analysed together). Pairwise $F_{\mathrm{ST}}$ values ranged from 0 to 0.132 (tests for differences between islands were not significant). The weighted $F_{\mathrm{ST}}$ across all loci across the five islands was 0.104 (Rousset, 1996), and Goodman's $R_{\mathrm{ST}}$ was 0.151 (Goodman, 1997). When analysing the historical data using the programme TESS, the highest log-likelihood value was obtained for $K=1$, suggesting the absence of population genetic structure. However, this finding should be treated with caution given the limitations imposed by the relatively small number of polymorphic markers used. Small sample size prevented a similar analysis for the contemporary population.

Fig. 2 gives the posterior distribution of the temporal change in historical and contemporary $N_{\mathrm{e}}$ for the Seychelles kestrel and Mauritius kestrel, as generated by the Bayesian analysis. The density of points is proportional to the probability density of population size at two different times, hence an off-diagonal distribution indicates a change in effective population size $\left(N_{\mathrm{e}}\right)$. The plot of the posterior distribution for the Mauritius kestrel (Beaumont, 2003, repeated here for comparison) provides very strong evidence of a recent decline in $N_{\mathrm{e}}$; the joint mode and $90 \%$ higher posterior density (HDP) limits for the marginals from the density estimation are $N_{\mathrm{e}}=957$ (390-1000) for the historical size and $N_{\mathrm{e}}=4.16$ (2.179.78 ) for the contemporary size, with a Bayes factor of $>9900$ in favour of recent population decline on Mauritius. In comparison, the posterior plot for the Seychelles kestrel shows a similar signature of recent reduction in effective population size, but with a joint mode of $N_{\mathrm{e}}=387$ for the historical size (90\% HPD limits, 1101000 ) and $N_{\mathrm{e}}=8$ for the contemporary population (90\% HPD limits, 3.5-22.0), indicating a population crash that was only marginally less severe than that experienced by the Mauritius kestrel. Given that the Seychelles kestrel appears to have recovered mostly in just a portion of its ancestral range, we carried out a repeated analysis restricted to just the Mahé samples (ancestral $n=14$ ) to estimate Mahé's ancestral $N_{\mathrm{e}}$, to determine the main island's contribution to the overall ancestral $N_{\mathrm{e}}$. As expected, this analysis produced a lower ancestral $N_{\mathrm{e}}$ of 264 , approximately $68 \%$ of the total ancestral $N_{\mathrm{e}}$. 

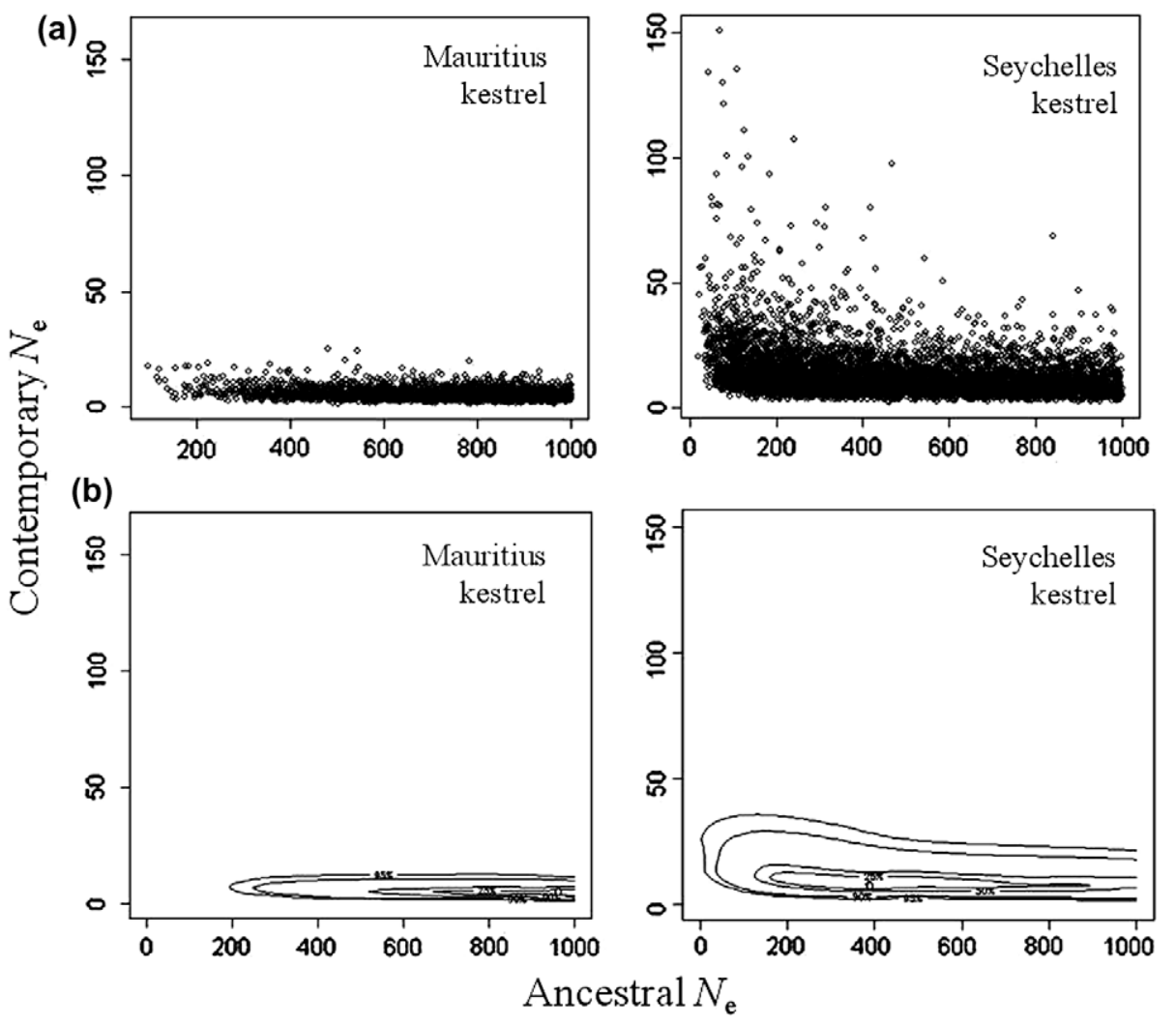

Fig. 2. Posterior distribution of the ancestral and contemporary effective population size $\left(N_{\mathrm{e}}\right)$ of the Seychelles kestrel and Mauritius kestrel, following the methods of Beaumont (2003). (a) The density of points is proportional to the probability density of population size at the two different times, hence an off-diagonal distribution indicates a change in $N_{\mathrm{e}}$ (note: the $y$-axis extends only to 150 ). (b) $25-95 \%$ higher posterior density limits of the posterior distribution. The joint mode is plotted as a single open circle.

\section{Discussion}

We consider the results for the museum samples to be very reliable; there was no sign of contamination, microsatellite genotype electropherogram peak heights were observed to be proportionally smaller than for equivalent contemporary genotypes from modern DNA sources (as would be expected from low copy number DNA template), replicates produced identical results (Pääbo et al., 2004), and we observed a higher number of polymorphic loci (including eight novel alleles) among the historical samples.

Our analysis of temporal genetic data for the Seychelles kestrel suggests that this species has endured a recent and severe population crash during the last 150 years to an estimated $N_{\mathrm{e}}$ of eight (3.5-22.0) individuals. A comparison of our genetic result for the Seychelles kestrel with a previous analysis of historical genotypes obtained for the Mauritius kestrel using the same suite of markers (Beaumont, 2003; Groombridge et al., 2000) suggests that the population crash experienced by the Seychelles kestrel may have approached the severity of that of the Mauritius species. Beaumont (2003) obtained a modal value of $N_{\mathrm{e}}=4$ for the contemporary Mauritius kestrel population, which is in close agreement with the lowest documented population size of four birds obtained from field surveys on Mauritius in 1974 (Jones et al., 1995; Groombridge et al., 2001). Consequently, our contemporary genetic estimate of an $N_{\mathrm{e}}$ of eight individuals adds credibility to claims made in the 1960s that the Seychelles kestrel was Critically Endangered and that the population on the main island of Mahé had declined at one point to 'less than 30 birds' (Vincent, 1966; Gaymer et al., 1969).

The genetic analysis described here is unable to determine precisely when the population crash experienced by the Seychelles kestrel occurred, but the distribution of collection dates for those individuals from which genetic data were obtained suggests that the most severe part of the population bottleneck occurred after 1940 (the collection date of the most recent historical museum skin) and prior to the onset of intensive field surveys in 1973, which detected close to 50 pairs (Feare et al., 1974; Temple, 1977). The most recent field surveys of the Seychelles kestrel in 2001-2002 indicate that the population has remained stable since the early 1980s (Kay et al., 2002). We note that the low contemporary estimate of genetic $N_{\mathrm{e}}$, described here as evidence of the severest extent of the population crash between the 1940s and 1970s, has been derived from the current population of Seychelles kestrels. Despite the recent recovery of the population to several hundred pairs, many future generations of mutation will be needed for the genetically estimated $N_{\mathrm{e}}$ to increase to ancestral levels.

If our genetic data for the Seychelles kestrel do indeed reflect the true historical trajectory of this island endemic, this case study provides some hope for the numerous other endemic island species whose populations are vulnerable to extinction. It would appear that the Seychelles kestrel has recovered from a severe population bottleneck with only minimal conservation efforts. The Seychelles kestrel population did not receive the level of intensive conservation management that occurred on Mauritius, where a 25-year long captive-breeding and reintroduction programme restored the Mauritius kestrel from just a handful of individuals in 1974 to over 800 birds by 2005 (Jones et al., 1995; Nicoll et al., 2004). By comparison, the Seychelles kestrel has received little active management; the species has been reintroduced by translocation to Praslin, but with limited success. In 1977, 13 kestrels were translocated from Mahé to Praslin where the species had previously been extirpated. By 1980 the Praslin population had grown to 10 pairs (Watson, 1989), but more recent surveys show the population has declined to just a handful of territories (Kay et al., 2004). 
Several ecological factors may explain the unaided recovery of the Seychelles kestrel. First, in contrast to Mauritius, where widespread and intensive use of DDT organochlorines between 1949 and 1965 is known to have directly contributed to the rapid decline of the Mauritius kestrel population by reducing eggshell thickness and associated productivity (Safford and Jones, 1997), on Seychelles the use of DDT was less widespread, being confined largely to small-scale trials by the Seychelles Government to control a variety of agricultural pests and localised house-to-house spraying during the 1940s-1960s (Seychelles Department of Agriculture, 1947; Mathias, 1971). Consequently, the ecological bioaccumulation of DDT is likely to have been considerably lower across the Seychelles archipelago than on Mauritius, thereby allowing the Seychelles kestrel population to rebound quickly following the end of DDT use. Second, habitat loss on Seychelles has been less severe than on Mauritius. On Mauritius, logging over the last 200 years removed almost all of the native ebony forest (Cheke, 1987; Safford, 1993), and, whilst commercial sugarcane plantations now cover most of the island, the kestrel's intensively-managed recovery has benefited from its ability to occupy suboptimal habitats (Jones et al., 1995). By comparison, large tracts of native habitat still remain across the Seychelles. Where degradation has occurred, the natural habitat has been replaced with large invasive trees such as cinnamon (Cinnamomum zeylanicum) and coconut (Cocos nucifera), but these species have helped to maintain a forest canopy and support the gecko and lizard populations that comprise the kestrel's prey (Stoddart, 1984; Watson, 1992; Groombridge et al., 2004). Intriguingly, the contemporary Seychelles kestrel population appears to have been slow to expand back into its former historical range. However, both the Mauritius and Seychelles kestrels are known to show limited dispersal and this may go some way to explaining their current distribution (Burgess et al., 2008).

Our modal estimate of ancestral $N_{\mathrm{e}}$ for the Seychelles kestrel of 387 , generated by genotyping of historical museum specimens collected between ca 1840 and 1940 , is less than half the equivalent estimate for the Mauritius kestrel of 957 that was obtained by a similar analysis of historical genotypes of similarly-aged museum specimens from Mauritius using the same suite of microsatellite markers (Beaumont, 2003). One factor that may explain this result is the difference in total island area (and hence ancestral carrying capacity) between Seychelles $\left(243 \mathrm{~km}^{2}\right)$ and Mauritius $\left(1650 \mathrm{~km}^{2}\right)$, suggesting a markedly lower ancestral carrying capacity on Seychelles.

It should be noted that the estimation of the mode of the ancestral $N_{\mathrm{e}}$ is somewhat uncertain and depends both on the density estimation procedure and the number of points sampled in the Monte Carlo Markov Chain. In particular, for the Mauritius kestrel the estimated mode for ancestral $N_{\mathrm{e}}$ is close to the limit set by the prior, and is probably indistinguishable from this limit. It is likely in this case that if the prior limit were increased, then the modal $N_{\mathrm{e}}$ would be correspondingly higher. In contrast, in the case of the Seychelles kestrel it appears, for example, that the 25\% HPD limit is well away from the upper limit of the prior, and thus the estimate of the mode is likely to be robust to any increase in the prior bounds (M. Beaumont, pers comm.). Our estimate of an ancestral $N_{\mathrm{e}}$ of 264 on Mahé alone provides further support for such relative differences in $N_{\mathrm{e}}$ in line with geographical area. The ancestral $N_{\mathrm{e}}$ estimate for Mahé accounts for $68 \%$ of the total ancestral $N_{\mathrm{e}}$, which is broadly in line with island size; Mahé $\left(144 \mathrm{~km}^{2}\right)$ accounts for $64 \%$ of the total $224 \mathrm{~km}^{2}$ area of those Seychelles islands believed to have formed the Seychelles kestrel's ancestral range.

As molecular genetic techniques become increasingly commonplace as an integral part of endangered species recovery programmes, there are more opportunities to compare evidence from demographic histories with temporal genetic data for other endan- gered island species (Shepard and Lambert, 2008). The picture emerging from these studies suggests that island populations can largely be categorized into those that have experienced ancient bottlenecks that caused prehistoric loss of genetic variation, such as those due to founding events or prehistoric changes in the environment, and those that have experienced recent bottlenecks, such as population crashes that have taken place over the last few hundred years. For example, Paxinos et al. (2002) showed a prehistoric decline in genetic variation in the endangered Hawaiian goose (Branta sandvicensis) that was concurrent with growth in the prehistoric human population on Hawaii. In contrast, the picture is less obvious for the South Island saddleback (Philesturnus carunculatus) from New Zealand, for which genetic data from historical museum specimens suggest that low contemporary levels of genetic variation in the Big South Cape Island population appear not be a consequence of a severe population crash caused by rat (Rattus spp.) infestations on the island in 1962. Instead, the low genetic variation is believed to be the consequence of a natural founding event (Taylor et al., 2007). Without this historical genetic information, managers working to conserve this saddleback population could have been misled by considering the ecological evidence alone.

Our genetic data provide evidence that the Seychelles kestrel has experienced a severe population crash within the last 70 years, in agreement with field surveys in the 1960s that indicated the species was 'critically endangered', and yet this island endemic appears to have recovered to a comparatively large population size in the absence of intensive conservation intervention. Similar examples of unaided species recoveries are extremely rare and many seemingly comparable 'unmanaged' species recoveries can often be explained by indirect intervention, such as broad-scale ecosystem management. For example, the endemic Rodrigues fody (Foudia flavicans) in the Mascarene Islands achieved a near 100 -fold increase in population size from fewer than 20 individuals in 1968 to a population of over 900 by 1999 in the absence of taxon-specific management (Impey et al., 2002), because the population had responded well to over a decade of extensive reforestation. Elsewhere, populations of species previously thought to be extinct have "reappeared", for example the Bermudan petrel (Pterodroma cahow) and the New Zealand takahe (Porphyrio hochstetteri; Lee and Jamieson, 2001). The survival and subsequent growth of these populations has largely resulted from many years of ecosystem management, often in parallel with intensive captivebreeding and reintroduction programmes. In contrast, the Seychelles kestrel appears to represent an unusual example of a relatively unassisted recovery from a small population size by an island endemic despite extensive loss of genetic diversity.

Of the 794 so-called 'trigger species' identified by Ricketts et al. (2005) to be at imminent risk of extinction unless immediate and direct conservation action is taken, 39\% are island species. Given the current pressure on global conservation resources, the undetected recovery of the Seychelles kestrel from a severe population crash may appear encouraging. However, outcomes such as this are likely to be the exception rather than the rule for other endangered island endemics.

\section{Acknowledgements}

This research was funded by a grant from the Royal Society to JG with further support by a Faculty Award from the University of Kent. The molecular genetic work was performed at the UK Natural Environmental Research Council's Molecular Genetics Facility. The research and associated fieldwork was approved by the Seychelles Bureau of Standards. Samples for the research were transported under CITES permits issued by the Conservation and National Parks Division, Department of Environment, Government of Seychelles. A. Huggins assisted with contemporary sample col- 
lection. Fieldwork and logistical support was also provided by staff at Nature Seychelles, including R. Bristol, U. Bristol, and T. Vel. Additional contemporary samples were also provided by Nature Seychelles and the Nature Protection Trust of the Seychelles. Museum samples were kindly made available by the following collections: Natural History Museum, Tring; University Museum of Zoology, Cambridge; World Museum Liverpool; Museum National d'Histoire Naturelle, Paris; American Museum of Natural History, New York. We thank A. Frantz and M. Beaumont for discussions of the manuscript.

\section{Appendix A}

\begin{tabular}{|c|c|c|c|c|}
\hline Museum & Catalogue \# & Collector & Year & Location \\
\hline 1 Paris & MNHN-457 & No data & - & - \\
\hline $2 \mathrm{NHM}$ & 1955.6.N20.1390 & Bishop of Mauritius & - & - \\
\hline 3 NHM & 1955.6.N20.1391 & Bishop of Mauritius & - & - \\
\hline 4 NHM & 1927.12.18.73 & Lister & - & - \\
\hline $5 \mathrm{NHM}$ & 1946.75 ex dup & No data & - & - \\
\hline 6 NHM & {$[18] 94.6 .16 .408$} & Ward & - & Mahé \\
\hline 7 Cambridge & CAM-13/Fal/1 & Newton & 1862 & Mahé \\
\hline 8 NHM & {$[18] 74.5 .13 .2$} & Newton & 1863 & - \\
\hline 9 Cambridge & CAM-13/Fal/6 & Brooks & 1866 & - \\
\hline 10 Cambridge & CAM-13/Fal/2 & Wright & 1867 & - \\
\hline 11 Cambridge & CAM-13/Fal/4 & Newton & 1867 & Mahé \\
\hline 12 Cambridge & CAM-13/Fal/7 & Newton & 1867 & Mahé \\
\hline $13 \mathrm{NHM}$ & 1955.6.N20.1387 & Newton & 1867 & Mahé \\
\hline 14 Cambridge & CAM-13/Fal/3 & Newton & 1867 & Praslin \\
\hline 15 Cambridge & CAM-13/Fal/8 & Newton & 1867 & Praslin \\
\hline 16 NHM & 1955.6.N20.1386 & W. A. Kennedy & 1867 & St. Anne \\
\hline 17 Liverpool & LIVER-T.1060 & Wright & 1861 & - \\
\hline 18 Cambridge & CAM-13/Fal/5 & Ward & 1869 & - \\
\hline 19 Paris & MNHN-496 & Lantz & 1878 & $\begin{array}{l}\text { Ile } \\
\text { Marianne }\end{array}$ \\
\hline 20 Paris & MNHN-501 & Lantz & 1878 & Mahé \\
\hline 21 Paris & MNHN-502 & Lantz & 1878 & Mahé \\
\hline 22 Paris & MNHN-498 & Lantz & 1878 & Praslin \\
\hline 23 Paris & MNHN-499 & Lantz & 1878 & Praslin \\
\hline 24 Liverpool & LIVER-T.3979 & Warry & 1879 & Felicite \\
\hline 25 NHM & 1955.6.N.20.1388 & 3 Warry & 1879 & Felicite \\
\hline $26 \mathrm{NHM}$ & 1955.6.N20.1389 & Warry & 1880 & Mahé \\
\hline 27 NHM & 1843.11.17.28 & No data & $\begin{array}{l}\mathrm{ca} \\
1840\end{array}$ & - \\
\hline 28 NHM & 1927.12.18.72 & Lister & 1888 & Mahé \\
\hline $29 \mathrm{AMNH}$ & AMNH-538713 & Mortimer & 1903 & Mahé \\
\hline $30 \mathrm{AMNH}$ & AMNH-538714 & Mortimer & 1903 & Mahé \\
\hline $31 \mathrm{AMNH}$ & AMNH-538715 & Thibault & 1904 & $\begin{array}{l}\text { Ile } \\
\text { Marianne }\end{array}$ \\
\hline $32 \mathrm{AMNH}$ & AMNH-538716 & Thibault & 1904 & $\begin{array}{l}\text { Ile } \\
\text { Marianne }\end{array}$ \\
\hline $33 \mathrm{AMNH}$ & AMNH-538717 & Thibault & 1904 & $\begin{array}{l}\text { Ile } \\
\text { Marianne }\end{array}$ \\
\hline $34 \mathrm{AMNH}$ & AMNH-538718 & Thibault & 1904 & $\begin{array}{l}\text { Ile } \\
\text { Marianne }\end{array}$ \\
\hline $35 \mathrm{AMNH}$ & AMNH-538719 & Thibault & 1904 & $\begin{array}{l}\text { Ile } \\
\text { Marianne }\end{array}$ \\
\hline $36 \mathrm{AMNH}$ & AMNH-538710 & Thibault & 1904 & Mahé \\
\hline $37 \mathrm{AMNH}$ & AMNH-538711 & Thibault & 1904 & Mahé \\
\hline 38 AMNH & AMNH-538712 & Thibault & 1904 & Mahé \\
\hline 39 AMNH & AMNH-538720 & Thibault & 1905 & Praslin \\
\hline $40 \mathrm{NHM}$ & 1906.12.21.185 & Nicoll & 1906 & Mahé \\
\hline $41 \mathrm{NHM}$ & 1906.12.21.184 & Nicoll & 1906 & Mahé \\
\hline 42 NHM & 1965.M.1565 & Meinertzhagen & 1910 & - \\
\hline $43 \mathrm{NHM}$ & 1946.75 .11 & $\begin{array}{l}\text { Sapsworth \& } \\
\text { Goodfellow }\end{array}$ & 1940 & Praslin \\
\hline
\end{tabular}

\section{References}

Ardern, S.L., Lambert, D.M., 1997. Is the black robin in genetic peril? Molecular Ecology 6, 21-28.

Bataillon, T., Kirkpatrick, M., 2000. Inbreeding depression due to mildly deleterious mutations in finite populations: size does matter. Genetics Research 75, 75-81.

Beaumont, M.A., 2003. Estimation of population growth or decline in genetically monitored populations. Genetics 164, 1139-1160.

Berger, D.D., Mueller, H.C., 1959. The bal-chatri: a trap for the birds of prey. BirdBanding 30, 18-26.

Bouzat, J.L., 2000. The importance of control populations for the identification and management of genetic diversity. Genetica 110, 109-115.

Bouzat, J.L., Lewin, H.A., Paige, K.N., 1998. The ghost of genetic diversity past: historical DNA analysis of the greater prairie chicken. American Naturalist 152 $1-6$.

Burgess, M.D., Nicoll, M.A.C., Jones, C.G., Norris, K., 2008. Restricted dispersal reduces the strength of spatial density dependence in a tropical bird population. Proceedings of the Royal Society B 275, 1209-1216.

Cheke, A.S., 1987. An ecological history of the Mascarene islands, with particular reference to extinctions and introductions of land vertebrates. In: Studies of Mascarene Island Birds. Cambridge University Press, Cambridge, UK, pp. 5-89.

Chen, C., Durand, E., Forbes, F., Francois, O., 2007. Bayesian clustering algorithms ascertaining spatial population structure: a new computer program and a comparison study. Molecular Ecology Notes 7, 747-756.

Collar, N.J., Stuart, S.N., 1985. Threatened Birds of Africa and Related Islands: The ICBP/IUCN Red Data Book. International Council for Bird Preservation, and International Union for Conservation of Nature and Natural Resources, Cambridge, UK.

Crook, J.H., 1960. The present status of certain rare land birds of the Seychelles islands. Seychelles Government Bulletin 1060 (January), 1-5.

Dawnay, N., Ogden, R., Wetton, J.H., Thorpe, R.S., McEwing, R., 2009. Genetic data from 28 STR loci for forensic individual identification and parentage analyses in six bird of prey species. Forensic Science International: Genetics 3, e63-e69.

England, P.R.G., Osler, H.R., Woodworth, L.M., et al., 2003. Effects of intense versus diffuse population bottlenecks on microsatellite genetic diversity and evolutionary potential. Conservation Genetics 4, 595-604.

Evans, S.R., Sheldon, B.C., 2008. Interspecific patterns of genetic diversity in birds: correlations with extinction risk. Conservation Biology 22, 1016-1025.

Feare, C.J., Temple, S.A., Procter, J., 1974. The status, distribution and diet of the Seychelles kestrel (Falco araea). Ibis 116, 548-551.

Frankham, R., 1997. Do island populations have less genetic variation than mainland populations? Heredity $78,311-327$

Frankham, R., 1998. Inbreeding and extinction: island populations. Conservation Biology 12, 665-675.

Frankham, R., 2005. Genetics and extinction. Biological Conservation 12, 131-140.

Frankham, R., Ballou, J.D., Briscoe, D.D., 2002. Introduction to Conservation Genetics. Cambridge University Press, Cambridge, UK.

Frankham, R., Gilligan, D.M., Morris, D., Briscoe, D.A., 2001. Inbreeding and extinction: effects of purging. Conservation Genetics 2, 279-284.

Gaymer, R., Blackman, R.A.A., Dawson, P.G., Penny, M.J., Penny, C.M., 1969. The endemic birds of Seychelles. Ibis 111, 157-176.

Goodman, S.J., 1997. $R_{\text {st }}$ calc: a collection of computer programs for calculating estimates of genetic differentiation from microsatellite data and a determining their significance. Molecular Ecology 6, 881-885.

Google Earth, 2007. Version 4.2.0205.5730.

Goudet, J., 2001. FSTAT: a program to estimate and test gene diversities and fixation indices (version 2.9.3). <http://www.unil.ch/izea/softwares/fstat.html>

Groombridge, J., 2007. Genetics and extinction of island endemics: the importance of historical perspectives. Animal Conservation 10, 147-148.

Groombridge, J.J., Jones, C.G., Bruford, M.W., Nichols, R.A., 2000. 'Ghost' alleles of the Mauritius kestrel. Nature 403, 616.

Groombridge, J.J., Bruford, M.W., Jones, C.G., Nichols, R.A., 2001. Estimating the severity of the population bottleneck in the Mauritius kestrel Falco punctatus from ringing records using MCMC estimation. Journal of Animal Ecology 70 401-409.

Groombridge, J.J., Nicoll, M.A., Jones, C.G., Watson, J., 2004. Associations of evolutionary and ecological distinctiveness amongst Indian Ocean kestrels. In: Chancellor, R.D., Meyburg, B.-U. (Eds.), Proceedings of the World Working Group on Birds of Prey \& Owls. Budapest, Hungary 19-23 May 2003, pp. 679692.

Impey, A.J., Côté, I.M., Jones, C.G., 2002. Population recovery of the threatened endemic Rodrigues fody (Foudia flavicans) (Aves, Ploceidae) following reforestation. Biological Conservation 107, 299-305.

International Union for Conservation of Nature, 2007. Red List of Threatened Species. Categories and Criteria: Version 3.1. IUCN Species Survival Commission. IUCN, Gland, Switzerland and Cambridge, UK.

Jamieson, I.G., 2007. Has the debate over genetics and extinction of island endemics truly been resolved? Animal Conservation 10, 139-144.

Jamieson, I.G., Wallis, G.P., Briskie, J.V., 2006. Inbreeding and endangered species management: is New Zealand out of step with the rest of the world? Conservation Biology 20, 38-47.

Jones, C.G., Heck, W., Lewis, R.E., Mungroo, Y., Slade, G., Cade, T.J., 1995. The restoration of the Mauritius kestrel Falco punctatus population. Ibis 137, S173S180. 
Kalinowski, S.T., Taper, M.L., Marshall, T.C., 2007. Revising how the computer program CERVUS accommodates genotyping error increases success in paternity assignment. Molecular Ecology 16, 1099-1106.

Kay, S., Millet, J., Watson, J., Shah, N.J., 2002. Status of the Seychelles kestrel Falco araea: a reassessment of the populations on Mahé and Praslin 2001-2002. Report by BirdLife Seychelles, Victoria, Mahé, Republic of Seychelles.

Kay, S., Millet, J., Watson, J., Shah, N.J., 2004. Status of the Seychelles kestrel Falco arae a on Praslin: an assessment of a re-introduced population on Praslin 20022003. Report by BirdLife Seychelles, Victoria, Mahé, Republic of Seychelles.

Keller, L.F., Grant, P.R., Grant, B.R., Petren, K., 2002. Environmental conditions affect the magnitude of inbreeding depression in survival of Darwin's finches. Evolution 56, 1229-1239.

Lee, W.G., Jamieson, I.G. (Eds.), 2001. The Takahe: Fifty Years of Conservation Management and Research. University of Otago Press, Dunedin, New Zealand.

Loustau-Lalanne, P., 1962. Land Birds of the Granitic Islands of the Seychelles. Seychelles Society Occasional Publication No. 1.

Madsen, T., Shine, I., Olsson, M., Wittzell, H., 1999. Restoration of an inbred adder population. Nature 402, 34-35.

Mathias, P.L., 1971. The Melittomma problem on Praslin island. Report to the Government of Seychelles Department of Agriculture, Victoria, Mahé, Republic of Seychelles, $43 \mathrm{p}$.

Matocq, M.D., Villablanca, F.X., 2001. Low genetic diversity in an endangered species: recent or historic pattern? Biological Conservation 98, 61-68.

Nesje, M., Roed, K.H., Lifjeld, J.T., Lindburg, P., Steen, O.F., 2000. Genetic relationships in the peregrine falcon (Falco peregrinus) analysed by microsatellite DNA markers. Molecular Ecology 9, 53-60.

Newton, E., 1867. On the land birds of the Seychelles archipelago. Ibis 3, 335-360.

Nichols, R.A., Bruford, M.W., Groombridge, J.J., 2001. Sustaining genetic variation in a small population: evidence from the Mauritius kestrel. Molecular Ecology 10, 593-602.

Nicoll, M.A.C., Jones, C.G., Norris, K., 2004. Comparison of survival rates of captivereared and wild-bred Mauritius kestrels (Falco punctatus) in a re-introduced population. Biological Conservation 118, 539-548.

Nielsen, E., Hansen, M.M., Loeschcke, V., 1999. Genetic variation in time and space: microsatellite analysis of extinct and extant populations. Evolution 53, 261268.

Paxinos, E.E., James, H.F., Olson, S.L., Ballou, J.D., Leonard, J.A., Fleischer, R.C., 2002. Prehistoric decline of genetic diversity in the Nene. Science 296, 1827.

Pääbo, S., Poinar, H., Serre, D., Jaenicke-Despres, V., Hebler, J., Rohland, N., Kuch, M., Krause, J., Vigilant, L., Hofrieter, M., 2004. Genetic analyses from ancient DNA. Annual Review of Genetics 38, 645-679.

Raymond, M., Rousset, F., 1995. GENEPOP (version 1.2): population genetics software for exact tests and ecumenicism. Journal of Heredity 86, 248-249.

Ricketts, T.H., Dinerstein, E., Boucher, T., et al., 2005. Pin-pointing and preventing imminent extinctions. Proceedings of the National Academy of Sciences of the USA 102, 18497-18501.

Rousset, F., 1996. Equilibrium values of measures of population subdivision for stepwise mutation processes. Genetics $142,1357-1362$

Safford, R.J., 1993. A survey of the occurrence of native vegetation remnants on Mauritius in 1993. Biological Conservation 80, 181-188.

Safford, R.J., Jones, C.G., 1997. Did organochlorine pesticide use cause declines in Mauritian forest birds? Biodiversity and Conservation 6, 1445-1451.
Seychelles Department of Agriculture, 1947. Annual Report of Department of Agriculture, Government of Seychelles, Victoria, Mahé, Republic of Seychelles.

Shepard, D.L., Lambert, D.M., 2008. Ancient DNA and conservation: lessons from the endangered kiwi from New Zealand. Molecular Ecology 17, 2174-2184.

Slatkin, M., 1995. A measure of population subdivision based on microsatellite allele frequency. Genetics 139, 457-462.

Spielman, D., Brook, B.W., Frankham, R., 2004. Most species are not driven to extinction before genetic factors impact them. Proceedings of the National Academy of Sciences of the USA 101, 15261-15264.

Stoddart, D.R., 1984. Impact of Man in the Seychelles. In: Stoddart, D.R. (Ed.), Biogeography and Ecology of the Seychelles Islands. Dr W. Junk Publishers, The Hague, pp. 641-654.

Swinnerton, K.J., Groombridge, J.J., Jones, C.G., Burn, R.W., Mungroo, Y., 2004. Inbreeding depression and founder diversity among captive and free-living populations of the endangered pink pigeon Columba mayeri. Animal Conservation $7,1-12$.

Taylor, S.S., Jamieson, I.G., 2008. No evidence for loss of genetic variation following sequential translocations in extant populations of a genetically depauperate species. Molecular Ecology 17, 545-556.

Taylor, S.S., Jamieson, I.G., Wallis, P., 2007. Historic and contemporary levels of genetic variation in two New Zealand passerines with different histories of decline. Journal of Evolutionary Biology 20, 2035-2047.

Temple, S.A., 1977. The status and conservation of endemic kestrels on the Indian Ocean islands. In: Chancellor, R.D. (Ed.), Proceedings of the World Conference on Birds of Prey, Vienna 1975. International Council for Bird Preservation, London, pp. 74-83.

Van Oosterhout, C., Hutchinson, W.F., Wills, D.P.M., Shipley, P., 2004. MICROCHECKER: software for identifying and correcting genotyping errors in microsatellite data. Molecular Ecology Notes 4, 535-538.

Van Oosterhout, C., Weetman, D., Hutchinson, W.F., 2006. Estimation and adjustment of microsatellite null alleles in non-equilibrium populations. Molecular Ecology Notes 6, 255-256.

Vesey-Fitzgerald, D., 1940. On the birds of the Seychelles 1-the endemic birds (land birds). Ibis $82,480-489$

Vincent, J., 1966. Red Data Book - Aves. International Union for Conservation of Nature and Natural Resources, Morges.

Watson, J., 1981. Population ecology, food and conservation of the Seychelles kestrel Falco araea on Mahé. Unpubl. PhD thesis. Aberdeen University.

Watson, J., 1989. Successful translocation of the endemic Seychelles kestrel Falco araea to Praslin. In: Meyburg, B.-U., Chancellor, R.D. (Eds.), Raptors in the Modern World. World Working Group on Birds of Prey and Owls, Berlin, pp. 363-367.

Watson, J., 1992. Nesting ecology of the Seychelles Kestrel Falco araea on Mahe, Seychelles. Ibis 134, 259-267.

Wattier, R., Engel, C.R., Saumitou-Laprade, P., Valero, M., 1998. Short allele dominance as a source of heterozygote deficiency at microsatellite loci: experimental evidence at the dinucleotide locus Gv1CT in Gracilaria gracilis (Rhodophyta). Molecular Ecology 7, 1569-1573.

Weir, B.S., Cockerham, C.C., 1984. Estimating F-statistics for the analysis of population structure. Evolution 38, 1358-1370. 
Kalinowski, S.T., Taper, M.L., Marshall, T.C., 2007. Revising how the computer program CERVUS accommodates genotyping error increases success in paternity assignment. Molecular Ecology 16, 1099-1106.

Kay, S., Millet, J., Watson, J., Shah, N.J., 2002. Status of the Seychelles kestrel Falco araea: a reassessment of the populations on Mahé and Praslin 2001-2002. Report by BirdLife Seychelles, Victoria, Mahé, Republic of Seychelles.

Kay, S., Millet, J., Watson, J., Shah, N.J., 2004. Status of the Seychelles kestrel Falco arae a on Praslin: an assessment of a re-introduced population on Praslin 20022003. Report by BirdLife Seychelles, Victoria, Mahé, Republic of Seychelles.

Keller, L.F., Grant, P.R., Grant, B.R., Petren, K., 2002. Environmental conditions affect the magnitude of inbreeding depression in survival of Darwin's finches. Evolution 56, 1229-1239.

Lee, W.G., Jamieson, I.G. (Eds.), 2001. The Takahe: Fifty Years of Conservation Management and Research. University of Otago Press, Dunedin, New Zealand.

Loustau-Lalanne, P., 1962. Land Birds of the Granitic Islands of the Seychelles. Seychelles Society Occasional Publication No. 1.

Madsen, T., Shine, I., Olsson, M., Wittzell, H., 1999. Restoration of an inbred adder population. Nature 402, 34-35.

Mathias, P.L., 1971. The Melittomma problem on Praslin island. Report to the Government of Seychelles Department of Agriculture, Victoria, Mahé, Republic of Seychelles, $43 \mathrm{p}$.

Matocq, M.D., Villablanca, F.X., 2001. Low genetic diversity in an endangered species: recent or historic pattern? Biological Conservation 98, 61-68.

Nesje, M., Roed, K.H., Lifjeld, J.T., Lindburg, P., Steen, O.F., 2000. Genetic relationships in the peregrine falcon (Falco peregrinus) analysed by microsatellite DNA markers. Molecular Ecology 9, 53-60.

Newton, E., 1867. On the land birds of the Seychelles archipelago. Ibis 3, 335-360.

Nichols, R.A., Bruford, M.W., Groombridge, J.J., 2001. Sustaining genetic variation in a small population: evidence from the Mauritius kestrel. Molecular Ecology 10, 593-602.

Nicoll, M.A.C., Jones, C.G., Norris, K., 2004. Comparison of survival rates of captivereared and wild-bred Mauritius kestrels (Falco punctatus) in a re-introduced population. Biological Conservation 118, 539-548.

Nielsen, E., Hansen, M.M., Loeschcke, V., 1999. Genetic variation in time and space: microsatellite analysis of extinct and extant populations. Evolution 53, 261268.

Paxinos, E.E., James, H.F., Olson, S.L., Ballou, J.D., Leonard, J.A., Fleischer, R.C., 2002. Prehistoric decline of genetic diversity in the Nene. Science 296, 1827.

Pääbo, S., Poinar, H., Serre, D., Jaenicke-Despres, V., Hebler, J., Rohland, N., Kuch, M., Krause, J., Vigilant, L., Hofrieter, M., 2004. Genetic analyses from ancient DNA. Annual Review of Genetics 38, 645-679.

Raymond, M., Rousset, F., 1995. GENEPOP (version 1.2): population genetics software for exact tests and ecumenicism. Journal of Heredity 86, 248-249.

Ricketts, T.H., Dinerstein, E., Boucher, T., et al., 2005. Pin-pointing and preventing imminent extinctions. Proceedings of the National Academy of Sciences of the USA 102, 18497-18501.

Rousset, F., 1996. Equilibrium values of measures of population subdivision for stepwise mutation processes. Genetics $142,1357-1362$

Safford, R.J., 1993. A survey of the occurrence of native vegetation remnants on Mauritius in 1993. Biological Conservation 80, 181-188.

Safford, R.J., Jones, C.G., 1997. Did organochlorine pesticide use cause declines in Mauritian forest birds? Biodiversity and Conservation 6, 1445-1451.
Seychelles Department of Agriculture, 1947. Annual Report of Department of Agriculture, Government of Seychelles, Victoria, Mahé, Republic of Seychelles.

Shepard, D.L., Lambert, D.M., 2008. Ancient DNA and conservation: lessons from the endangered kiwi from New Zealand. Molecular Ecology 17, 2174-2184.

Slatkin, M., 1995. A measure of population subdivision based on microsatellite allele frequency. Genetics 139, 457-462.

Spielman, D., Brook, B.W., Frankham, R., 2004. Most species are not driven to extinction before genetic factors impact them. Proceedings of the National Academy of Sciences of the USA 101, 15261-15264.

Stoddart, D.R., 1984. Impact of Man in the Seychelles. In: Stoddart, D.R. (Ed.), Biogeography and Ecology of the Seychelles Islands. Dr W. Junk Publishers, The Hague, pp. 641-654.

Swinnerton, K.J., Groombridge, J.J., Jones, C.G., Burn, R.W., Mungroo, Y., 2004. Inbreeding depression and founder diversity among captive and free-living populations of the endangered pink pigeon Columba mayeri. Animal Conservation $7,1-12$.

Taylor, S.S., Jamieson, I.G., 2008. No evidence for loss of genetic variation following sequential translocations in extant populations of a genetically depauperate species. Molecular Ecology 17, 545-556.

Taylor, S.S., Jamieson, I.G., Wallis, P., 2007. Historic and contemporary levels of genetic variation in two New Zealand passerines with different histories of decline. Journal of Evolutionary Biology 20, 2035-2047.

Temple, S.A., 1977. The status and conservation of endemic kestrels on the Indian Ocean islands. In: Chancellor, R.D. (Ed.), Proceedings of the World Conference on Birds of Prey, Vienna 1975. International Council for Bird Preservation, London, pp. 74-83.

Van Oosterhout, C., Hutchinson, W.F., Wills, D.P.M., Shipley, P., 2004. MICROCHECKER: software for identifying and correcting genotyping errors in microsatellite data. Molecular Ecology Notes 4, 535-538.

Van Oosterhout, C., Weetman, D., Hutchinson, W.F., 2006. Estimation and adjustment of microsatellite null alleles in non-equilibrium populations. Molecular Ecology Notes 6, 255-256.

Vesey-Fitzgerald, D., 1940. On the birds of the Seychelles 1-the endemic birds (land birds). Ibis $82,480-489$

Vincent, J., 1966. Red Data Book - Aves. International Union for Conservation of Nature and Natural Resources, Morges.

Watson, J., 1981. Population ecology, food and conservation of the Seychelles kestrel Falco araea on Mahé. Unpubl. PhD thesis. Aberdeen University.

Watson, J., 1989. Successful translocation of the endemic Seychelles kestrel Falco araea to Praslin. In: Meyburg, B.-U., Chancellor, R.D. (Eds.), Raptors in the Modern World. World Working Group on Birds of Prey and Owls, Berlin, pp. 363-367.

Watson, J., 1992. Nesting ecology of the Seychelles Kestrel Falco araea on Mahe, Seychelles. Ibis 134, 259-267.

Wattier, R., Engel, C.R., Saumitou-Laprade, P., Valero, M., 1998. Short allele dominance as a source of heterozygote deficiency at microsatellite loci: experimental evidence at the dinucleotide locus Gv1CT in Gracilaria gracilis (Rhodophyta). Molecular Ecology 7, 1569-1573.

Weir, B.S., Cockerham, C.C., 1984. Estimating F-statistics for the analysis of population structure. Evolution 38, 1358-1370. 